\title{
BMJ Global Health An urgent call to collect data related to COVID-19 and Indigenous populations globally
}

\author{
Alistair Mallard (D , ${ }^{1}$ Maria Amalia Pesantes, ${ }^{2}$ Carol Zavaleta-Cortijo, ${ }^{3}$ \\ James Ward ${ }^{1,4}$
}

\begin{abstract}
To cite: Mallard A, Pesantes MA, Zavaleta-Cortijo C, et al. An urgent call to collect data related to COVID-19 and Indigenous populations globally. BMJ Global Health 2021;6:e004655. doi:10.1136/ bmjgh-2020-004655
\end{abstract}

Handling editor Seye Abimbola

Received 3 December 2020 Revised 10 February 2021 Accepted 10 February 2021

Check for updates

(C) Author(s) (or their employer(s)) 2021. Re-use permitted under CC BY-NC. No commercial re-use. See rights and permissions. Published by BMJ.

${ }^{1}$ Poche Centre for Indigenous Health, The University of Queensland, Brisbane, Queensland, Australia ${ }^{2}$ Department of Anthropology and Archaeology, Dickinson College, Carlisle, Pennsylvania, USA

${ }^{3}$ School of Public Health, Universidad Peruana Cayetano Heredia, Lima, Peru ${ }^{4}$ School of Public Health, The University of Queensland, Brisbane, Queensland, Australia

Correspondence to Dr Alistair Mallard; a.mallard@uq.edu.au

\section{INTRODUCTION}

SARS-CoV-2 which causes COVID-19 emerged in Wuhan, China in December 2019 and has now reached pandemic status. ${ }^{1}$ As of 31 January 2021, COVID-19 has been detected in 188 countries/regions and all continents except Antarctica. A total of more than 100 million cases have been detected so far with some countries showing disproportionately more cases than others, in particular the USA, Brazil, Russia, India, Peru and Mexico. ${ }^{2}$ Currently, it is understood that SARS-CoV-2 is spread through respiratory droplets and direct contact. ${ }^{1}$ The reproduction number $\left(\mathbf{R}_{0}\right)$ of SARS-CoV-2 has been estimated to be in the range of 1.40-6.49 with a mean of 3.28. Any virus with an $\mathrm{R}_{0}$ above 1 is indicative of $\mathrm{a}$ virus with increasing number of infections. ${ }^{3}$

Globally thus far, efforts to curb the spread of SARS-CoV-2 have resulted with varying success. Countries such as China, Australia and New Zealand, which have implemented widespread lockdown of social gathering, restricted movement and quarantine (for returning residents), seem to have curbed the early spread of SARS-CoV-2, ${ }^{2}$ although are susceptible to recurring waves as has occurred in many European countries recently. Contrariwise, in nations with less strict pandemic governance arrangements including social distancing policies and adherence, or a removal of once imposed restrictions (eg, USA, Brazil and Iran), the incidence of the virus continues to escalate rapidly. ${ }^{4}$ Even within countries that have relatively contained the spread of COVID-19, disparities have been noted among identifiable population groups such as the elderly, prisoners, healthcare workers, migrants, refugees and Indigenous peoples. ${ }^{5}$ Here we discuss COVID-19 cases, outcomes and challenges for Indigenous peoples globally.
Summary box

Globally, Indigenous populations have fared poorly in relation to their non-Indigenous counterparts in previous pandemics hence it is important to assess how they are faring in the COVID-19 pandemic.

- Due to the vulnerability of Indigenous people to more severe outcomes of COVID-19 because of both historical and contemporary issues impacting overall health status, timely and accurate data should be urgently collated and reported.

- This study highlights major gaps in data collation and analysis of COVID-19 by Indigenous status.

- In countries where there appears to be good control of COVID-19, this has benefits for Indigenous peoples; conversely the same is true.

- Without available epidemiological data on Indigenous populations, it will also be difficult to justify vaccine prioritisation for these populations in some countries.

Indigenous peoples live in over 90 countries globally and account for some 476 million individuals or $\sim 6.2 \%$ of the global population. ${ }^{6}$ Despite recent efforts to improve the health and well-being of Indigenous peoples, disparities exist between Indigenous and nonIndigenous peoples where data are available. Issues such as earlier life expectancy, disparate rates of infant mortality, chronic diseases and mental health continue to be common issues affecting Indigenous populations globally. Much of this burden of disease is driven by poor outcomes in many of the social determinants of health, and the ongoing impact of colonisation, marginalisation and discrimination. Indigenous peoples hold significant cultural heritage and understanding of the ways of environment and humanity living harmoniously together. Many Indigenous groups continue to use their medical traditions to address their health problems, sometimes in unison with western medical care at public health facilities. Many have endured 
previous pandemics prior to colonisation and the global hegemony of western medicine.

Given the intersectionality of social determinants of health, marginalisation within dominant colonised populations and underlying health disparities, Indigenous peoples are more likely to experience more severe outcomes (hospitalisation and death) resulting from COVID-19 than their non-Indigenous counterparts. ${ }^{6}$ Previous pandemics have highlighted this vulnerability. In 2009, during the influenza A virus subtype H1N1 pandemic, diagnosis rates and deaths were higher in Indigenous populations than their non-Indigenous counterparts. The Australian Indigenous population, Aboriginal and Torres Strait Islander peoples, experienced notifications and hospitalisations at 3.5 and 12 times, respectively, the rate recorded among non-Indigenous peoples. ${ }^{7}$ Similarly, the mortality rates among Indigenous peoples of the Brazilian Amazon were 4.5 times higher than non-Indigenous peoples ${ }^{8}$; and in the USA, higher rates of mortality were recorded among non-Hispanic American Indian and Alaskan Native (AI/AN) persons with a mortality rate ratio four times that of non-AI/AN. ${ }^{9}$

The United Nations Department of Economic and Social Affairs has released a policy brief regarding the impact of SARS-CoV-2 on Indigenous populations. ${ }^{10}$ Citing the impacts already noted in Indigenous populations such as the Navajo Nation, Maasai of Kenya and Batwa of Rwanda, their recommendations include: recognition of Indigenous peoples by governments, inclusion of Indigenous peoples representatives in committees, and support of Indigenous communities during lockdowns and reconstruction activities, among others. Congruently, the United Nations also recognises the lack of information available to truly assess the impact of SARS-CoV-2 on Indigenous peoples.

To understand the burden of SARS-CoV-2 on Indigenous populations, we sought to document cases among Indigenous peoples to place a spotlight on these communities. Our intent is to show the importance of developing specific pandemic plans and responses for Indigenous peoples locally and globally. We contacted jurisdictional health authorities to gather information regarding the number of cases and deaths of COVID-19 in both Indigenous and non-Indigenous populations. We also searched peer-reviewed and grey literature including government and institute websites, databases between 1 June and 3 November 2020. Data are presented as number per 100000 individuals.

\section{DATA QUALITY AND AVAILABILITY}

We found major gaps in the reporting of SARS-CoV-2 among Indigenous peoples globally with just nine countries being able to publicly report notifications and mortality data as listed in table 1 (accurate and available as of 24 November 2020).

Where data are available in the majority of these countries, COVID-19 cases were lower among Indigenous populations than their non-Indigenous counterparts except for Brazil, Peru and the USA. We also found that within countries there are significant disparities between Indigenous and non-Indigenous peoples. This is evident in regions where the majority of the population are Indigenous such as in isolated or remote regions as in Navajo Nation in the USA or the Ucayali region in Peru, and Saskatchewan in Canada. ${ }^{11}$

\section{DATA COLLECTION VARIABILITY}

In some countries, Indigenous peoples have fared relatively well and others not. Notification rates of SARS-CoV-2 are reported six times less among Aboriginal and Torres Strait Islander people in Australia than their non-Indigenous counterparts; in New Zealand, among Maori peoples 1.7 times less than other New Zealanders; and in Canada among First Nations peoples 3.2 times less than other Canadians although the situation is changing rapidly especially for Indigenous peoples living on reservations. In all three countries, access to timely, complete and accurate data has both enabled COVID-19 Indigenous-specific preparedness and response plans to be implemented early. In these three countries, Indigenous peoples have also been involved in the development of preparedness and response plans specific to their populations. ${ }^{12}$ Australia's comprehensive COVID-19 data collation on notifications, testing rates and outcomes including among Indigenous peoples should be seen as the gold standard. Since the beginning of the pandemic, data are available by region, age and sex for notifications, testing and hospitalisations.

Other Indigenous peoples, however, such as AIs and ANs in the USA, and Indigenous peoples in the Ucayali region of Peru, have experienced higher cases per population and a higher case fatality rate than their nonIndigenous counterparts. These countries also have some of the highest number of cases of COVID-19 per population globally. It is difficult to ascertain preparedness and response plans specific to these Indigenous populations and if so they were developed as a response to increasing cases, late into the pandemic, highlighting the need for early preparedness for all populations particularly those most vulnerable in society. Several organisations in Peru, Brazil, Ecuador and Colombia have raised concerns globally about inadequate responses and have repeatedly called for assistance to provide protection of their populations and demanding action against their respective governments. ${ }^{13}$

\section{DATA COLLECTION STANDARDS}

We believe that due to the global nature of the SARS-CoV-2 pandemic, a global and standardised approach of data collation specific for Indigenous populations, the sharing of this sharing, transparency and collaboration is needed to curb the devastating toll of SARS-CoV-2, as previously described by Zavaleta. ${ }^{14}$ 


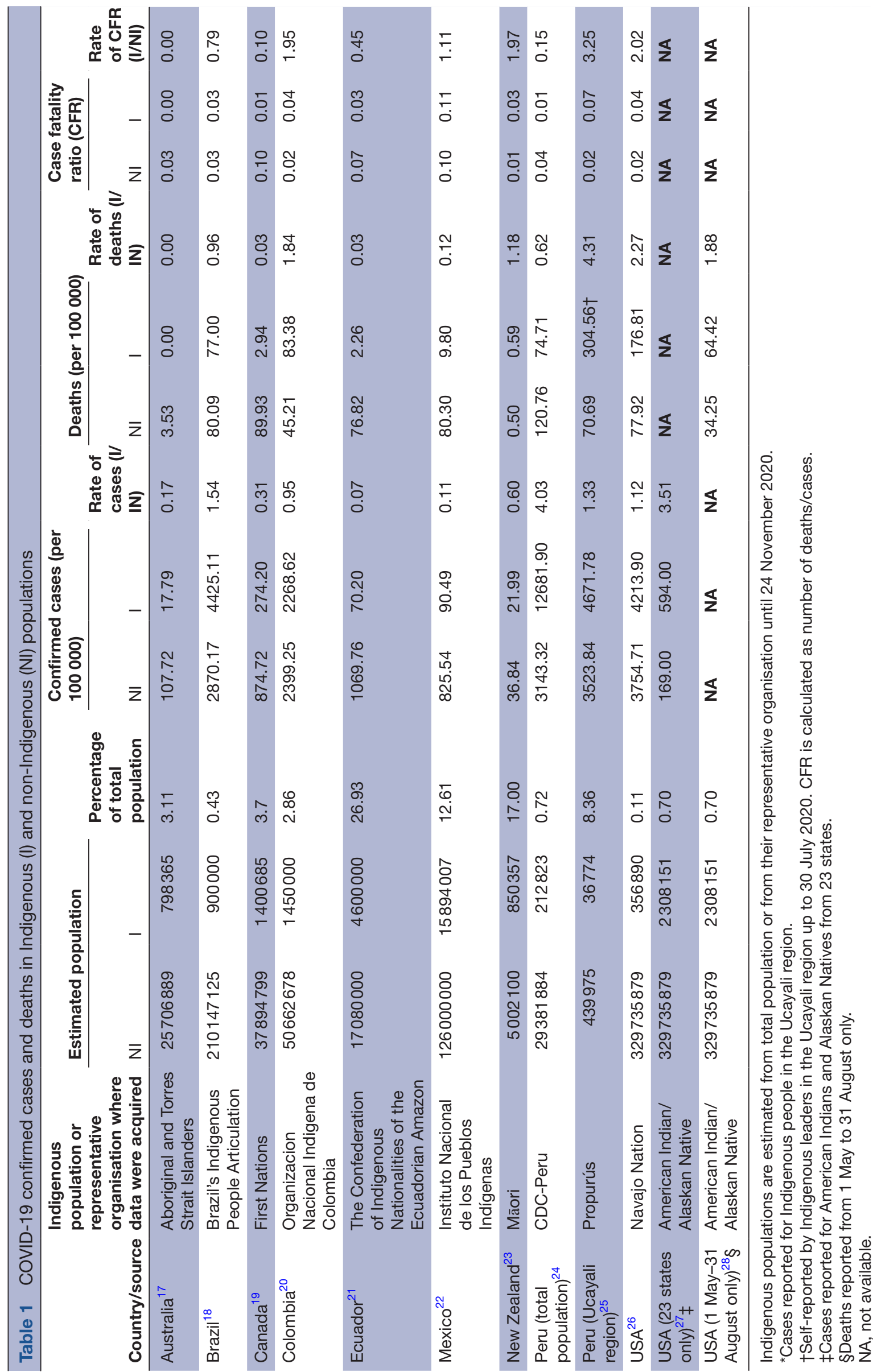


It is important for COVID-19 now but important for all other communicable diseases. Governments globally should collect and provide data on Indigenous communities for the main purpose of preparedness and response to the COVID-19 pandemic. Sharing data globally ensures accountability for most vulnerable populations. Failure to do so can and will potentially wipe out Indigenous peoples and their cultures that have existed for many thousands of years.

There are some limitations of this approach to our collation of data: many countries with Indigenous populations also do not register the ethnicity of population at time of diagnosis; some countries did not want to share Indigenous data, despite existing recommendations to do so and so we are not able to report cases by Indigenous status.

Other countries have no publicly available data on Indigenous cases or outcomes from COVID-19. We argue that with limited or no information publicly available regarding Indigenous peoples and COVID-19, there is a hindrance in decision-making for Indigenous peoples, and in doing so this potentially minimises the impact and the ability to curb infections with tailored approaches appropriate for Indigenous peoples. Finally, where there are available data among Indigenous peoples many do not disaggregate by regions of residence and often Indigenous peoples living in urban environments are masked within broader population groups.

\section{SELF-GOVERNANCE}

The COVID-19 pandemic has shown the capacity of Indigenous peoples themselves to control the spread of the virus among Indigenous peoples. Many Indigenous populations around the world have taken preventative action above and beyond that of the recommendations of their local and federal governments, including selfisolation and border control to tribal lands. ${ }^{15}$ Yet, sometimes the government policies themselves have blocked these measures, such as the case of Peru, when the government decision to provide financial assistance to poor Peruvians through cash transfers resulted in otherwise not infected Indigenous peoples travelling to towns where banks were located, becoming infected and taking the virus back to traditional lands. ${ }^{16}$

\section{CONCLUSIONS}

During the current pandemic, we found major gaps in reporting SARS-CoV-2 infections and outcomes among Indigenous peoples. We urge the collection of Indigenous ethnicity data regarding the number of cases, hospitalisation and mortality of COVID-19, for other disease states and for future pandemics. Transparency for Indigenous populations should be paramount in global governance agendas. Informative, inclusive and participatory decision-making and policy creation is key to preventing and limiting the spread of SARS-CoV-2 among Indigenous populations who are at a greater risk of losing cultural phenomena and shared histories that belong to humankind.

Twitter Alistair Mallard @dralmallard

Acknowledgements The authors would like to acknowledge the front-line healthcare workers and data custodians who gathered the data.

Contributors AM and JW designed the presented idea. All authors performed the literature search, data collection, data analysis and data interpretation. AM and JW wrote the first draft of the manuscript. All authors contributed to editing and finalising the manuscript.

Funding The authors have not declared a specific grant for this research from any funding agency in the public, commercial or not-for-profit sectors.

Disclaimer The views expressed are those of the authors and not necessarily those of Wellcome, the NIHR or the Department of Health and Social Care.

Competing interests MAP was supported by a postdoctoral grant funded by the Swiss National Science Foundation and the Swiss Development Cooperation under the Swiss Program for Research on Global Issues for Development (IZ08Z0_177385). CZ-C was supported by the National Institute for Health Research (NIHR) (using the UK's Official Development Assistance (ODA) Funding) and Wellcome (218743/Z/19/Z) under the NIHR-Wellcome Partnership for Global Health Research; and is member of the Indigenous Health and Adaptation to Climate Change Research Group. JW is supported by the Sylvia and Charles Viertel Senior Medical Research Fellowship.

Patient consent for publication Not required.

Provenance and peer review Not commissioned; externally peer reviewed.

Data availability statement All data relevant to the study are included in the article.

Open access This is an open access article distributed in accordance with the Creative Commons Attribution Non Commercial (CC BY-NC 4.0) license, which permits others to distribute, remix, adapt, build upon this work non-commercially, and license their derivative works on different terms, provided the original work is properly cited, appropriate credit is given, any changes made indicated, and the use is non-commercial. See: http://creativecommons.org/licenses/by-nc/4.0/.

\section{ORCID iD}

Alistair Mallard http://orcid.org/0000-0002-7961-1458

\section{REFERENCES}

1 Shi Y, Wang G, Cai X-P, et al. An overview of COVID-19. J Zhejiang Univ Sci B 2020;21:343-60.

2 Centers for Disease Control and Prevention JHU. COVID-19 Dashboard, 2020. Available: https://gisanddata.maps.arcgis.com/ apps/opsdashboard/index.html\#/bda7594740fd40299423467b 48e9ecf6 [Accessed 02 Jul 2020].

3 Liu Y, Gayle AA, Wilder-Smith A, et al. The reproductive number of COVID-19 is higher compared to SARS coronavirus. J Travel Med 2020;27:taaa021.

4 British Broadcasting Company. Coronavirus: has a second wave of infections hit Iran? 2020. Available: https://www.bbc.com/news/ 52959756

5 Franco-Paredes C, Jankousky K, Schultz J, et al. COVID-19 in jails and prisons: a neglected infection in a marginalized population. PLoS Negl Trop Dis 2020;14:e0008409.

6 Gracey M, King M. Indigenous health Part 1: determinants and disease patterns. Lancet 2009;374:65-75.

7 Flint SM, Davis JS, Su J-Y, et al. Disproportionate impact of pandemic (H1N1) 2009 influenza on Indigenous people in the top end of Australia's Northern Territory. Med J Aust 2010;192:617-22.

8 La Ruche G, Tarantola A, Barboza P, et al. The 2009 pandemic $\mathrm{H} 1 \mathrm{~N} 1$ influenza and Indigenous populations of the Americas and the Pacific. Euro Surveill 2009;14:19366.

9 Centers for Disease Control and Prevention (CDC). Deaths related to 2009 pandemic influenza A (H1N1) among American Indian/ Alaska Natives - 12 states, 2009. MMWR Morb Mortal Wkly Rep 2009;58:1341-4

10 United Nations Department of Economics and Social Affairs. UN/ DESA Policy Brief \#70: The Impact of COVID-19 on Indigenous Peoples, 2020. Available: https://www.un.org/development/desa/ 
dpad/publication/un-desa-policy-brief-70-the-impact-of-covid-19on-indigenous-peoples/

11 Allen B. Largest outbreak of COVID-19 in an Indigenous community in Canada offers important lessons, 2020. Available: https://www. cbc.ca/news/canada/saskatchewan/outbreak-covid-19-indigenouscommunity-lessons- 1.5737126

12 Department of Health AG. Management plan for Aboriginal and Torres Strait Islander populations, 2020. Available: https://www. health.gov.au/resources/publications/management-plan-foraboriginal-and-torres-strait-islander-populations

13 Cervantes M. Peru indigenous warn of 'ethnocide by inaction' as coronavirus hits Amazon tribes Reuters2020. Available: https://www. reuters.com/article/us-health-coronavirus-peru-indigenous/peruindigenous-warn-of-ethnocide-by-inaction-as-coronavirus-hitsamazon-tribes-idUSKCN22639A?il=0

14 Zavaleta C. COVID-19: review Indigenous peoples' data. Nature 2020;580:185

15 World Economic Forum. Why it's vital indigenous communities protect their elders from coronavirus, 2020. Available: https://www.weforum. org/agenda/2020/05/latin-americas-indigenous-protect-coronavirus/

16 Cárdenas C, Belaunde L, Reymundo L. COVID-19: government policies as a vector of contagion, 2020. Available: https://www. servindi.org/actualidad-informe-especial/27/06/2020/covid-19-laspoliticas-del-gobierno-como-un-vector-de

17 Department of Health AG. Coronavirus (COVID-19) health alert, 2020. Available: https://www.health.gov.au/news/health-alerts/novelcoronavirus-2019-ncov-health-alert

18 Brazil's Indigenous People Articulation. Brazil's Indigenous People Articulation, 2020. Available: http://apib.info/apib/?lang=en
19 Indigenous Services Canada CG. Coronavirus (COVID-19) and Indigenous communities, 2020. Available: https://www.sac-isc.gc. ca/eng/1581964230816/1581964277298\#chap0

20 Organizacion Nacional Indigena de Colombia. Organizacion Nacional Indigena de Colombia, 2020. Available: https://www.onic. org.co/

21 The Confederation of Indigenous Nationalities of the Ecuadorian Amazon. Monitoreo de COVID-19, 2020. Available: https://arcg.is/ 04PrTv0

22 Instituto Nacional de los Pueblos Indígenas. Instituto Nacional de Los Pueblos Indígenas, 2020. Available: https://www.gob.mx/inpi

23 Ministry of Health NZ. COVID-19 (novel coronavirus), 2020. Available: https://www.health.govt.nz/our-work/diseases-andconditions/covid-19-novel-coronavirus

24 National Center for Epidemiology Peru. Reporte de la Población Indígena de la Amazonía, 2020. Available: https://www.dge.gob.pe/ portalnuevo/informacion-publica/sala-de-poblacion-indigena-concovid-19/

25 Propurus. COVID-19 cases in the native communities of Ucayali, 2020. Available: https://propurus.org/

26 Navajo Nation Department of Health. Dikos Ntsaaigii (COVID-19), 2020. Available: https://www.ndoh.navajo-nsn.gov/COVID-19

27 Hatcher SM, Agnew-Brune C, Anderson M, et al. COVID-19 Among American Indian and Alaska Native Persons - 23 States, January 31-July 3, 2020. MMWR Morb Mortal Wkly Rep 2020;69:1166-9.

28 Gold JAW, Rossen LM, Ahmad FB, et al. Race, Ethnicity, and Age Trends in Persons Who Died from COVID-19 - United States, MayAugust 2020. MMWR Morb Mortal Wkly Rep 2020;69:1517-21. 